\title{
PENGEMBANGAN MEDIA PEMBELAJARAN $U$-ECO UNTUK MENINGKATKAN MOTIVASI BELAJAR PESERTA DIDIK KELAS X IPS 1 SMA N 4 BANGKALAN TAHUN AJARAN 2018/2019
}

\author{
ALFARABI \\ Program Studi Pendidikan Ekonomi, Jurusan Pendidikan Ekonomi, Fakultas Ekonomi, Universitas Negeri \\ Surabaya \\ alfarabialfarabi@mhs.unesa.ac.id
}

\begin{abstract}
ABSTRAK
Penelitian ini bertujuan, 1) mengembangkan media $U$-Eco pada materi bank sub alat pembayaran., 2) mengetahui kelayakan pengembangan media $U$-Eco., 3) mengetahui peningkatan motivasi belajar siswa setelah menggunakan media pembelajaran $U$-Eco. Penelitian ini dilaksanakan dengan memakai metode Research and Development dan memakai model 4D oleh Tiagarajan, Semmel and semmel (1974). Penelitian ini memiliki beberapa tahapan, meliputi, 1) define (pendefinisian); 2) design (perancangan); 3) develop (pengembangan); dan disseminate (penyebaran) dikarenakan adanya keterbatasan waktu, biaya dan kemampuan tenaga oleh peneliti, maka tahap ini tidak dijalankan.berikut adalah beberapa hasil yang didapatkan pada penelitian ini yaitu, 1) media $U$-Eco telah berhasil dikembangkan melalui metode penelitian dan pengembangan R\&D dengan model 4D, 2) Kelayakan media pembelajaran $U$-Eco dinilai berdasarkan pada: a) Ahli Materi didapatkan rata-rata skor 90 yang dapat dikategorikan Sangat Layak, b) Ahli Media didapatkan skor 93 yang dikategorikan Sangat Layak, dan c) Ahli Evaluasi Butir Soal didapatkan rata-rata skor 100 yang dapat dikategorikan Sangat Baik; 3) media U-Eco yang dikembangkan mendapat peningkatan motivasi belajar peserta didik dengan uji gain score sebesar 0,41 dengan kategori Sedang. Dapat disimpulkan bahwa berdasarkan hasil penilaian ahli materi, ahli media, ahli evaluasi pada media yang dikembangkan dinyatakan layak dan berdasarkan peningkatan skor motivasi belajar peserta didik dapat dinyatakan bahwa media pembelajaran $U$-Eco dapat meningkatkan motivasi belajar peserta didik.
\end{abstract}

Kata kunci : Media Pembelajaran, $U$-Eco dan Motivasi Belajar

\begin{abstract}
The purpose of this research, 1) develop U-Eco media on bank material for payment instruments., 2) determine the feasibility of developing U-Eco media., 3) find out the increase in students' learning motivation after U-Eco learning media. This research was conducted using the Research and Development method using the 4D model by Tiagarajan, Semmel and Semmel (1974). The stages of this study include, 1) defining (define); 2) design; 3) development (develop); and dissemination, but this stage is not carried out because there are limits on the ability of labor, cost and time by researchers. The results shown in this study are, 1) U-Eco media has been successfully developed through $R \& D$ research and development methods with the $4 D$ model, 2) The feasibility of $U$-Eco learning media is assessed based on: a) Material Expert obtained an average score of 90 which belongs to the category of Very Eligible, b) Media Expert obtained a score of 93 which belongs to the category of Very Eligible, and c) Expert Evaluation of Item Grains obtained an average score of 100 which belongs to the category of Very Good; 3) U-Eco media developed has an increase in students' learning motivation with a gain score test of 0.41 in the Medium category. It can be concluded that based on the results of the assessment of material experts, media experts, evaluation experts on the developed media declared feasible and based on increasing students 'learning motivation scores it can be stated that U-Eco learning media can increase learners' motivation
\end{abstract}

Keywords: Learning Media, U-Eco, Learning Motivation.

\section{PENDAHULUAN}

Proses pembelajaran adalah serangkaian kegitan belajar mengajar yang telah disusun oleh pengajar. Dalam proses pembelajaran terdapat 2 pelaku utama, yakni guru sebagai pendidik dan murid atau siswa sebagai peserta didik. Proses pembelajaran merupakan kegiatan paling inti dalam sistem pendidikan karena langsung bersinggungan secara psikomotorik, kognitif dan afektif terhadap peserta didik. Proses pembelajaran inilah yang paling menentukan kualitas output dari suatu lembaga pendidikan. Faktorfaktor yang dapat mempengaruhi proses pembelajaran dapat dibedakan menjadi 2 kategori, yakni 1) faktor internal dan 2) faktor eksternal. Faktor internal disini 
terdiri dari faktor psikologis dan fisiologis. Beberapa faktor psikologis yang dapat mempengaruhi proses pembelajaran antara lain: kecerdasan peserta didik; motivasi; minat; sikap; dan bakat. Jadi, motivasi merupakan salah satu faktor yang dapat memengaruhi kualitas proses pembelajaran. (Baharuddin \& Wahyuni, 2015)

Motivasi adalah sesuatu yang menyebabkan, mempertahankan, dan mengarahkan perilaku individu (Slavin, 2009). Motivasi dapat dikataan sebagai bahan bakar individu untuk menjalankan sesuatu untuk memenuhi kebutuhan. Hal ini sesuai dengan pendapat Winkel (2004) menyatakaan bahwa motivasi belajar merupakan adanya keseluruhan daya gerak psikis didalam diri peserta didik dan memberikan arah pada kegiatan belajar mengajar (KBM) kemudian menjamin kelangsungan KBM demi mencapai suatu tujuan. Jadi motivasi belajar merupakan suatu hal yang mendorong peserta didik agar untuk berbuat, untuk tetap berbuat dan menentukan tujuan dari melakukan aktifitas tersebut. Jadi, semakin kuat motivasi belajar peserta didik, maka semakin semangat untuk melakukan kegiatan belajar. Sebaliknya, semakin lemah motivasi belajar peserta didik, maka akan semakin malas untuk melakukan kegiatan belajar.

Menurut (Sadiman et al., 2011), motivasi belajar peserta didik dapat diukur dengan indikator: Tekun dalam menghadapi tugas, Ulet menghadapi kesulitan, Menunjukan minat terhadap pelajaran, Lebih senang bekerja sendiri, Cepat bosan pada tugas-tugas yang rutin, Dapat mempertahankan pendapatnya, Tidak mudah melepaskan hal yang telah diyakini, Senang mencari dan memecahkan soal-soal. Apabila dikaitkan dengan fenomena pada saat pembelajaran mata pelajaran ekonomi, dari factor yang pertama yaitu peserta didik jarang mengumpulkan tugas yang cenderung sulit untuk dikerjakan, peserta didik tidak mau berusaha lebih untuk memahami materi, peserta didik kurang tertarik untuk mempelajari mata pelajaran ekonomi, lebih senang belajar atau memngerjakan tugas secara berkelompok, mudah bosan dengan tugas yang cenderung sama secara bentuk, tidak mampu mempertahankan argumentasi apabila ada sanggahan, mudah melepaskan pemahaman yang telah diyakini apabila kalah dalam adu argument, kurang senang mencari soal tambahan. Jadi, dapat diidentifikasi bahwa peserta didik kelas X IPS 1 SMAN 4 Bangkalan memiliki motivasi rendah.

Menurut Gage \& Berliner (dalam Slameto, 2010) mengatakan bahwa salah satu cara meningkatkan motivasi belajar peserta didik dapat menggunakan simulasi dan permainan. Permainan merupakan kontestasi antara para pemain/kelompok yang saling berinteraksi dengan mengikuti suatu aturan untuk mencapai suatu tujuan (Sadiman et al., 2011). Pembelajaran berbasis permainan telah menjadi tren saat ini untuk mendukung pendidikan abad ke-21 (Azizan et al., 2018). Menurut Nurhasanah, Herliawan, \& Pertawati (2013), Modifikasi permainan yang dikembangkan sebagai sarana media pembelajaran merupakan suatu cara alternatif dalam membantu peserta didik dan pendidik saat proses pembelajaran berlangsung. Permainan untuk media proses belajar mengajar memiliki kelebihan meliputi; permainan adalah sebuah hal yang mengasikkan untuk dilakukan, terdapat interaksi pembelajaran, dan dapat memberikan feed back secara langsung maupun tidak langsung, dapat menerapkan konsep yang sudah melekat di masyarakat, memiliki sifat luwes dengan memodifikasi alat atau peraturan, ataupun jumlah peserta mudah diperbanyak. Jadi, dengan media permainan sebagai media pembelajaran peserta didik lebih dapat terlibat langsung dalam pembelajaran sehingga membuat peserta didik lebih termotivasi serta mampu berkomunikasi secara aktif. Penelitian ini didukung oleh (Lepper \& Cordova, 1992), (Sung \& Ching, 2012), (Sari et al., 2016), (Wityanto \& Rahmawati, 2017), (Supriyono et al., 2018), (Batson \& Feinberg, 2005), (Turkay et al., 2012).

Salah satu teori konstruktivisme adalah teori perilaku yang diperkenalkan oleh Bhurrus Frederic Skinner. Ia mendalilkan bahwa teori perilaku adalah fungsi dari konsekuensinya (Kearsley dalam Batson \& Feinberg, 2005). Teori perilaku dalam desain game digunakan untuk mempelajari aturan dasar permainan dan menunjukkan rangsangan terhadap sikap atau perilaku pemain lain. Pemain mendapatkan umpan balik positif atau negatif langsung maupun tidak langsung dalam permainan untuk merespons berdasarkan pengalaman sebelumnya. Sebagai contoh dalam permainan kartu uno, saat ada pemain lain mengeluarkan kartu +4 , kita akan berusaha untuk menangkal efek yang dikeluarkan oleh kartu tersebut jika kita memiliki kartu yang sama. Jika kita tidak mempunyai kartu tersebut, maka harus menerima efeknya. Akan tetapi, semua pemain di arena tahu bahwa jumlah kartu tersebut semakin berkurang, jadi kemungkinan pemain lain untuk mengeluarkannya semakin kecil. Oleh karenanya, teori konstruktivisme dapat diterapkan pada permainan.

Albert Enstein menjelaskan ide relativitas khusus dengan menganalogikan ada titik waktu ketika kita memainkan game dan kita kehilangan waktu dan ruang yang sebenarnya. Saat ada orang lain berbicara mungkin 
tampaknya kita memperhatikan mereka. Tapi saat kita menanggapi, mereka tampak terkejut ternyata kita tidak memperhatikan apa yang mereka katakan. Ini berarti bahwa kita sangat fokus pada kegiatan yang sedang dikerjakan sehingga tidak bisa fokus ada hal lain. Ini adalah imersif (Kalmpourtzis, 2019). Jadi, teori immersif adalah suatu keadaan pikiran di mana fokus seseorang begitu diarahkan pada suatu topik sehingga segala sesuatu berlalu begitu saja tanpa disadari. Teori ini biasa diterapkan dalam permainan. Sehingga saat pemain memainkan permainan dan masuk dalam dunia imersif, maka permainan tersebut dapat memotivasi dan menarik. Imersif ini dapat dijumpai di permainan kartu Uno Economy, yang selanjutkan akan disingkat $U$-Eco.

$U$-Eco adalah sebuah permainan yang dimainkan 4 sampai 5 orang atau kelompok dan satu juri. Cara bermain dan komponen $U$-Eco sedikit mirip dengan permainan kartu uno semestinya, tapi pada $U$-Eco terdapat kartu tema, kartu soal dan kartu materi. Setiap kartu materi memiliki uraian materi yang diharapkan peserta didik dapat memahami konsep dasar materinya dan dibarengi dengan bermain. Pada permainan U-Eco juga terdapat kartu simbol dan kartu soal yang bisa di pakai untuk merancang strategi dalam permainan. Titik keseruan dalam permainan ini adalah saat para pemain saling membalas kartu simbol dan kartu soal sebagai suatu upaya untuk menghambat jalan menangnya pemain lain. Sehingga setiap pemain akan saling berkompetisi untuk mencapai kemenangan. Dalam pembelajaran partisipasi peserta secara tidak langsung akan tumbuh melalui konsep permaianan kartu - kartu tersebut. Sehingga efek yang diharapkan dapat meningkatkan motivasi belajar. Guru akan bersedia menggunakan media tersebut karena permainan ini bersifat flexible dalam menggunakan alat dalam arti tidak banyak memakai alat bantu seperti LCD (Licuid Crystal Display) dan White Screen ataupun laptop untuk memainkannya, pilihan lokasi bermain menjadi lebih banyak karena tidak membutuhkan banyak tempat dan syarat, aturan permainan ini cenderung lebih sederhana sehingga lebih mudah dipahami bahkan oleh orang yang baru pertama kali bermain.

Berdasarkan uraian yang telah dijelaskan di atas peneliti menetapkan tujuan penelitian: 1) mendeskripsikan pengembangan media pembelajaran $U$-Eco kelas X IPS-1 SMA Negeri 4 Bangkalan; 2) menganalisis kelayakan media pembelajaran $U$-Eco kelas X IPS-1 SMA Negeri 4 Bangkalan; 3) Untuk mengetahui peningkatan motivasi belajar peserta didik kelas X IPS-1 SMA Negeri 4
Bangkalan setelah menggunakan media pembelajaran $U$ Eco".

\section{METODE PENELITIAN}

Metode penelitian yang diterapkan adalah 4D yang dipaparkan oleh Thiagarajan semmel and semmel. Adapun alur tahapan penelitian yang dilaksanakan yakni, define (tahap pendefinisian), design (tahap perancangan), dan develop (tahap pengembangan), namun tahapan ini memiliki keterbatasan antara lain; waktu, tenaga, dan biaya oleh peneliti sehingga tahap penyebaran (disseminate) tidak diterapkan.

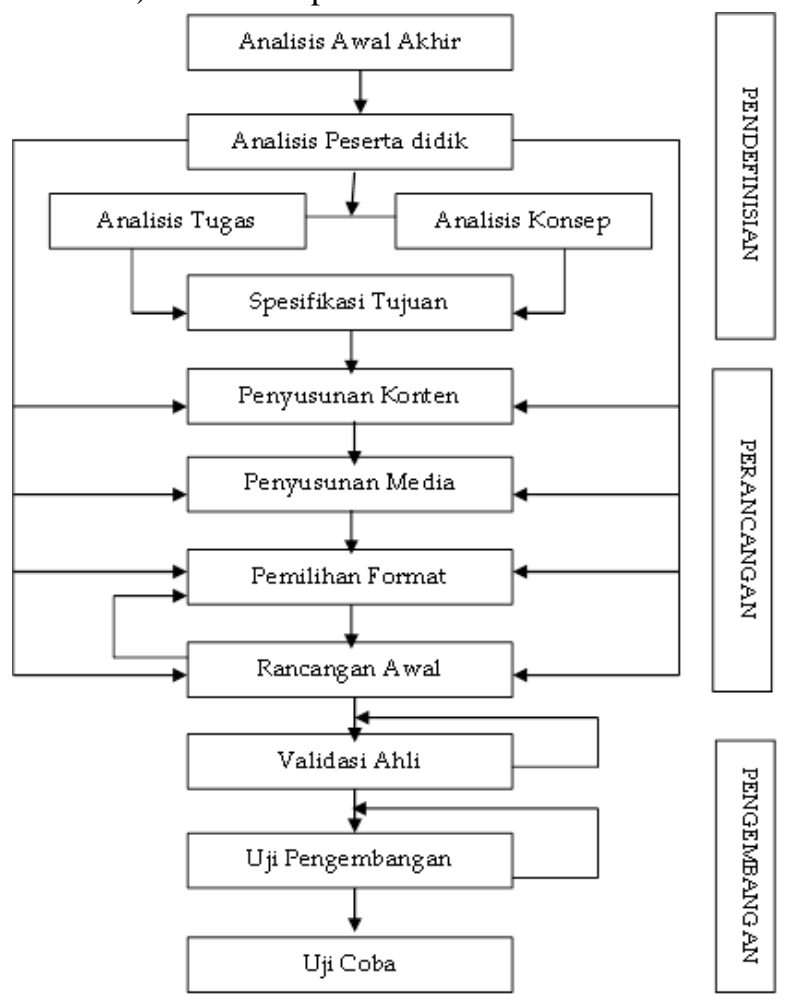

Gambar 1 Rancangan Model Pengembangan 4D Media Pembelajaran $U$-Eco

Sumber: Dimodifikasi dari Thiagarajan, Semmel, dan Semmel (dalam Trianto, 2007)

Pertama adalah tahap defne (pendefinisian) yaitu tahap utama dalam penelitian yang akan menganalisis melalui 5 langkah yakni (1) analisis awal akhir, (2) analisis peserta didik, (3) analisis tugas, (4) analisis konsep, (5) analisis perumusan tujuan pembelajaran. Kedua adalah tahap design (perancangan) yaitu tahap menyusun draf perangkat pembelajaran melalui beberapa langkah seperti (1) penyusunan konten, (2) penyusunan media, (3) pemilihan format, (4) rancangan awal. Ketiga tahap develop (pengembangan) yaitu media yang dikembangkan akan divalidasi dan ditelaah oleh oleh para ahli untuk 
mengetahui kelayakan bahan ajar dengan beberapa langkah seperti: (1) validasi ahli, (2) uji pegembangan, (3) uji coba lapangan.

Subjek uji coba dari penelitian ini adalah 20 peserta didik kelas X IPS 1 SMA N 4 Bangkalan. Desain penelitian yang digunakan adalah Pre-Experimental dengan model One-Group Pretest-Posttest Design yang merupakan model penerapan pretest yang diberikan salah satu kelompok sebelum treatment atau perlakuan dan posttest. Pretest-posttest diberikan untuk mengetahui peningkatan variabel kontrol, yakni motivasi belajar peserta didik. Berikut adalah gambar model One Group Pretest-Posttest Design:

\begin{tabular}{|lll|}
\hline $\mathbf{O}_{1}$ & $*$ & $\boldsymbol{O}_{2}$ \\
\hline
\end{tabular}

Sumber: Sugiyono (2017)

\section{Keterangan :}

$\mathbf{O}_{1} \quad$ : Pre-Test berupa angket

$\mathbf{O}_{2} \quad$ : Post-Test berupa angket

X : Perlakuan

Subjek penelitian dan pengembangan ini adalah dua dosen ahli materi, dua dosen ahli evaluasi, dua dosen ahli media dan 20 siswa kelas X IPS 1 SMA Negeri 4 Bangkalan. Dalam penelitian ini terdapat dua jenis data yang digunakan yakni data 1) data kuantitatif; 2) Data kualitatif. Data kualitatif didapatkan dari hasil observasi, wawancara serta komentar dan saran dari ahli materi, ahli media, dan ahli evaluasi. Data kuantitatif didapatkan dari hasil penilaian ahli materi, ahli media, ahli evaluasi, dan angket motivasi belajar peserta didik.

Adapun instrumen dalam pengumpulan data pada penelitian ini peneliti memakai media, kuesioner atau angket dan validasi ahli materi, ahli media, serta ahli evaluasi dan angket motivasi belajar peserta didik. Pada lembar instrumen validasi ahli materi, ahli media, dan angket motivasi belajar siswa atau peserta didik menggunakan skala Likert ( Riduwan, 2016). Sedangkan pada kuesioner lembar telaah dan validasi ahli evaluasi menggunakan skala Guttman (Riduwan, 2016). Skala likert adalah skala yang diterapkan dalam mengukur sikap, pendapat, dan persepsi pemikiran individu atau kelompok terkait dengan gejala atau kejadian sosial (Riduwan, 2016). Di sisi lain Skala Guttman adalah skala kumulatif guna menjawab pertanyaan dengan sikap jelas atau tegas (Riduwan, 2016).

Lembar instrumen validasi ahli materi dan media memuat kriteria penilaian dengan skor 1 "sangat tidak layak", 2 "tidak layak", 3 "sedang", 4 "layak" dan 5 "sangat layak". Lembar instrumen motivasi belajar peserta didik memuat kriteria dengan penilaian skor 1 "sangat tidak setuju", 2 "tidak setuju”, 3 "kurang setuju”, 4 "setuju" dan 5 "sangat setuju". Kemudian untuk lembar validasi ahli evaluasi butir soal berisi kriteria dengan penilaian "ya" skor 1 dan "tidak" skor 0. Setelah didapatkan hasil dari penilaian lembar validasi para ahli dan angket motivasi belajar peserta didik lalu data akan dianalisis dan didapatkan hasil dengan kriteria interpretasi. Kriteria tersebut dapat diuraikan pada tabel di bawah ini:

Tabel 1 Kriteria Interpretasi Skor Validasi Ahli Media dan Ahli Materi

\begin{tabular}{cccccc}
\hline Presentase & $81 \%-$ & $61 \%-$ & $41 \%-$ & $21 \%-$ & $0 \%-$ \\
& $100 \%$ & $80 \%$ & $60 \%$ & $40 \%$ & $20 \%$ \\
\multirow{3}{*}{ Kriteria } & Sangat & Layak & Sedang & Tidak & Sangat \\
& Layak & & & Layak & Tidak \\
& & & & & Layak
\end{tabular}

Sumber: Diadaptasi dalam Riduwan (2016)

Tabel 2 Kriteria Interpretasi Skor Validasi Ahli Evaluasi Butir Soal

\begin{tabular}{cccccc}
\hline Presentase & $81 \%-$ & $61 \%-$ & $41 \%-$ & $21 \%-$ & $0 \%-$ \\
& $100 \%$ & $80 \%$ & $60 \%$ & $40 \%$ & $20 \%$ \\
\multirow{2}{*}{ Kriteria } & Sangat & Layak & Sedang & Tidak & Sangat \\
& Layak & & & Layak & Tidak \\
& & & & & Layak \\
\hline
\end{tabular}

Sumber: Diadaptasi dalam Riduwan (2016)

Tabel 3 Kriteria Interpretasi Skor Motivasi Belajar Peserta Didik

\begin{tabular}{lccc}
\hline $\begin{array}{l}\text { Niali gain } \\
\text { score }\end{array}$ & $(\mathrm{g}) \geq 0,7$ & $0,3 \leq(\mathrm{g})<0,7$ & $(\mathrm{~g})<0,3$ \\
Kategori & Tinggi & Sedang & Rendah \\
\hline
\end{tabular}

Sumber: (Hake, 1999)

HASIL DAN PEMBAHASAN

Proses Pengembangan Media Pembelajaran $U$-Eco

Hasil penelitian dan pengembangan media $U$-Eco pada pembelajaran berdasarkan model 4D yang terbatas pada tahap develop (pengembangan). Tahap pertama yaitu define (pendefinisian) memiliki 5 tahapan, antara lain: (a) analisis awal akhir diketahui bahwa sekolah sudah menerapkan Kurikulum 2013 Revisi akan tetapi eksekusi di dalam kelas masih menggunakan metode tradisional. Pada materi bank sub materi alat pembayaran yang memiliki banyaknya 
penggunaan istilah asing sehingga peserta didik kurang dapat memahami materi dengan mudah. Peserta didik juga teridentifikasi memiliki motivasi belajar rendah; (b) analisis siswa atau peserta didik menjelaskan bahwa siswa lebih bersemangat untuk belajar saat menggunakan permainan. Selain dengan permainan, stimulus berupa hadiah dan hukuman juga dapat mendongkrak motivasi belajar; (c) analisis tugas diketahui bahwa dalam media pembelajaran $U$-Eco disajikan dalam bentuk multiple choice (pilihan ganda) sebanyak 15 butir soal dan 10 butir soal berbentuk essay yang bertujuan untuk membantu peserta didik yang memiliki kesulitan dalam memahami materi pelajaran serta untuk mengetahui materi pelajaran yang telah dikuasai peserta didik. Pilihan ganda dan essay merupakan bentuk soal yang sederhana sehingga cocok diterapkan dalam materi bank sub materi alat pembayaran yang memiliki banyak istilah asing; (d) analisis konsep yang diterapkan pada materi bank dengan sub materi alat pembayaran sebagai berikut:

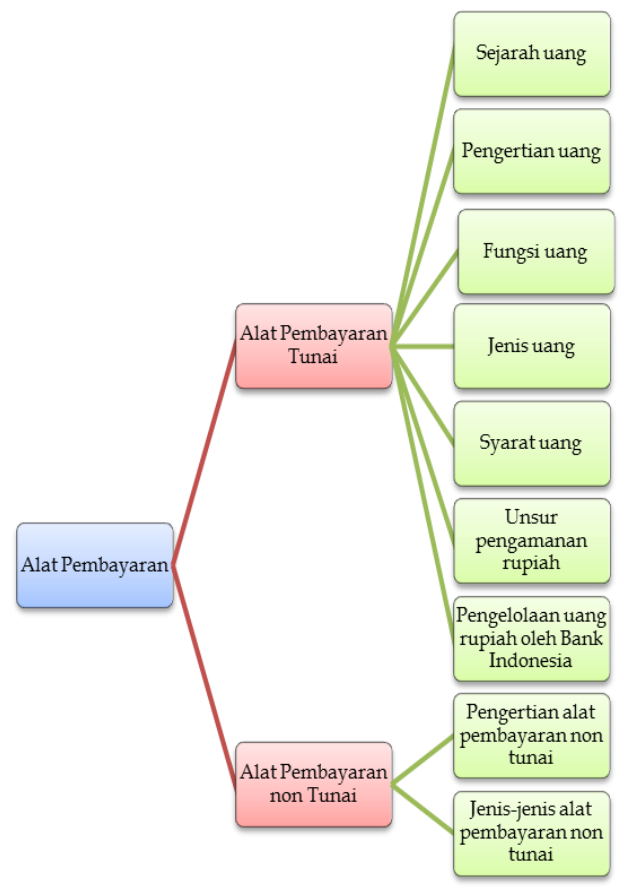

\section{Gambar 2 Peta Konsep Materi}

Sumber: diolah peneliti (2019)

e) analisis tujuan pembelajaran pada pengembangan media pembelajaran U-Eco diselaraskan dengan Kompetensi Dasar (KD) dan indikator pada materi bank sub materi alat pembayaran.

Tahap kedua yakni design (perancangan). Pada tahap ini peneliti merancang media dengan beberapa langkah, antara lain: a) menentukan materi dan soal berdasarkan silabus KD 3.5, yakni materi bank sub materi alat pembayaran; b) menentukan jumlah kartu yang akan pakai dalam media pembelajaran $U$-Eco; c) menentukan jenis, ukuran, warna, dan font isi konten yang akan di pakai pada media pembelajaran $U-E c o$; d) Menyusun Guide Book media pembelajaran U-Eco yang berisi petunjuk penggunaan media, perawatan media, rancangan pelaksanaan pembelajaran, panduan materi singkat, serta soal dan kunci jawaban; e) Warna kuning yang dominan dalam cover produk dan Guide Book yang bertujuan untuk mengangkat semangat, optimisme, dan emosional peserta didik. Di samping itu, warna kuning merupakan warna terkuat secara psikologis; f) Gambar batik motif kacangan pada kartu tema dan kartu materi bertujuan untuk melestarikan warisan leluhur madura.

Tahap yang ketiga pada proses pengembangan 4D oleh Thiagarajan semmel and semmel adalah tahap pengembangan (develop). Dalam tahap ini peneliti mendapat hasil perangkat atau media pembelajaran yang sudah direvisi berdasar pada saran dan komentar para ahli (Trianto, 2007). Data hasil saran dan komentar tersebut diperoleh dari lenbar telaah atau angket validasi yang disediakan oleh peneliti dan di isi oleh ahli materi, ahli media, dan ahli evaluasi. Saran dan komentar para ahli tersebut di pakai untuk bahan acuan perbaikan media pembelajaran U-Eco agar layak digunakan dan dimanfaatkan dengan baik serta menjawab kebutuhan peserta didik dalam proses pembelajaran.

Ahli materi memberi saran agar sub materi tentang pengelolaan uang oleh Bank Indonesia diperbarui. Lalu ahli media memberikan saran agar ditambahkan keterangan bahwa "disarankan untuk yang pernah bermain kartu uno pada umumnya" pada cover media. Kemudian ahli evaluasi memberikan saran agar interval pilihan soal pada pilihan ganda disusun sesuai dengan kaidah penulisan soal, memperbaiki kata kerja operasional agar sesuai dengan indikator soal, dan memperbaiki level kognitif soal menurut Taksonomi Bloom.

Setelah peneliti melakukan perbaikan sesuai dari hasil telaah para ahli, lalu dilakukan proses validasi oleh para ahli sesuai dengan kriteria penilaian yang telah ditetapkan. Setelah menyelesaiakan prosedur telaah dan validasi maka media pembelajaran $U$-Eco siap diuji cobakan pada sampel berjumlah 20 orang yang di ambil dari siswa kelas X IPS 1SMA Negeri 4 Bangkalan.

\section{Kelayakan Media Pembelajaran $\boldsymbol{U}$-Eco}

Kelayakan media $U$-Eco dari hasil validasi para ahli yang meliputi ahli media, ahli evaluasi, dan ahli materi. Para ahli melakukan penilaian berdasarkan pada angket 
validasi yang sudah disiapkan. Adapun hasil validasi oleh ahli materi yang telah diisi oleh Dhiah Fitrayati, S.Pd., M.E. selaku dosen jurusan Pendidikan Ekonomi UNESA, dan Dra. Adriani selaku guru pengampu mata pelajaran ekonomi SMA N 4 Bangkalan adalah sebagai berikut:

Tabel 4 Hasil Rekapitulasi Validasi Ahli Materi

\begin{tabular}{lll}
\hline Aspek & $\begin{array}{l}\text { Rata-rata } \\
\text { Presentase }\end{array}$ & Kriteria \\
\hline $\begin{array}{l}\text { Kualitas Isi } \\
\text { Dan Tujuan }\end{array}$ & $91,11 \%$ & Sangat Layak \\
$\begin{array}{l}\text { Kualitas } \\
\text { Intruksional }\end{array}$ & $90 \%$ & Sangat Layak \\
$\begin{array}{l}\text { Kualitas } \\
\text { Teknik } \\
\text { Rata-rata } \\
\text { Keseluruhan }\end{array}$ & $88 \%$ & Sangat Layak \\
\hline
\end{tabular}

Sumber : data diolah peneliti (2019)

Berdasarkan data tabel di atas dapat diuraikan bahwa perolehan hasil validasi dari ahli materi pada media pembelajaran U-Eco mendapat rata-rata sebesar $90 \%$ dengan kategori sangat layak. Sedangkan hasil validasi oleh ahli media yang telah diisi oleh Khusnul Khotimah, S.Pd., M.Pd. selaku dosen jurusan teknologi pendidikan UNESA adalah sebagai berikut:

Tabel 5 Hasil Rekapitulasi Validasi Ahli Media

\begin{tabular}{|c|c|c|}
\hline Aspek & $\begin{array}{l}\text { Rata-rata } \\
\text { Presentase }\end{array}$ & Kriteria \\
\hline $\begin{array}{l}\text { Kualitas Isi } \\
\text { Dan Tujuan }\end{array}$ & $93,33 \%$ & Sangat Layak \\
\hline $\begin{array}{l}\text { Kualitas } \\
\text { Intruksional }\end{array}$ & $92 \%$ & Sangat Layak \\
\hline $\begin{array}{l}\text { Kualitas } \\
\text { Teknik }\end{array}$ & $93,33 \%$ & \\
\hline $\begin{array}{l}\text { Rata-rata } \\
\text { Keseluruhan }\end{array}$ & $93 \%$ & Sangat Layak \\
\hline
\end{tabular}

Sumber : data diolah peneliti (2019)

Berdasarkan data tabel di atas dapat uraikan bahwa perolehan hasil validasi oleh ahli media mendapat rata-rata sebesar 93\% dengan kategori sangat layak. Kemudian hasil validasi oleh ahli evaluasi yang telah di isi oleh Dhiah Fitrayati, S.Pd., M.E. selaku dosen jurusan Pendidikan Ekonomi UNESA, dan Dra. Adriani selaku guru pengampu mata pelajaran ekonomi SMA N 4 Bangkalan adalah sebagai berikut:adalah sebagai berikut:

Tabel 6 Hasil Rekapitulasi Validasi Ahli Evaluasi
Rata-rata Kriteria

\begin{tabular}{lll}
\hline & Presentase & \\
\hline Materi & $100 \%$ & Sangat Layak \\
Konstruksi & $100 \%$ & Sangat Layak \\
Bahasa & $100 \%$ & Sangat Layak \\
Rata-rata & $100 \%$ & Sangat Layak \\
Keseluruhan & & \\
\hline
\end{tabular}

Sumber : data diolah peneliti (2019)

Berdasarkan tabel di atas dapat diketahui bahwa perolehan hasil validasi oleh ahli evaluasi mendapat ratarata sebesar $100 \%$ dengan kategori sangat layak atau dengan kata lain setiap indikator telah terdistribusi dengan rata pada setiap soal yang dicantumkan dalam media pembelajaran $U$-Eco.

\section{Peningkatan Motivasi Belajar Peserta Didik}

Peningkatan motivasi belajar peseta didik dapat diketahui dengan menghitung selisih skor angket motivasi belajar sebelum menggunakan media pembelajaran $U$-Eco dan sesudah menggunakan media pembelajaran $U$-Eco.

Tabel 7 Data Hasil Motivasi Belajar Peserta Didik

\begin{tabular}{|c|c|c|c|c|}
\hline No & Pernyataan & Jumlah & $\begin{array}{l}\text { Rata } \\
\text {-rata } \\
(\%)\end{array}$ & $\begin{array}{l}\text { Peningkatan } \\
(\%)\end{array}$ \\
\hline 1 & $\begin{array}{l}\text { Motivasi } \\
\text { belajar peserta } \\
\text { didik Sebelum } \\
\text { Penggunaan } \\
\text { Media }\end{array}$ & 1209 & 75.56 & \\
\hline 2 & $\begin{array}{l}\text { Motivasi } \\
\text { belajar peserta } \\
\text { didik Setelah } \\
\text { Penggunaan } \\
\text { Media }\end{array}$ & 1371 & 85.69 & 10.13 \\
\hline \multicolumn{5}{|c|}{ Sumber : data diolah peneliti (2019) } \\
\hline \multicolumn{5}{|c|}{$\begin{array}{l}\text { Berdasarkan data pada tabel enam dapat diuraikan } \\
\text { bahwa terjadi pertubuhan motivasi belajar peserta didik } \\
\text { sebesar } 10,13 \% \text { dari } 75,56 \% \text { (motivasi belajar sebelum } \\
\text { diberi tindakan) menjadi } 85,69 \% \text { (motivasi belajar setelah } \\
\text { diberi tindakan). Untuk mengetahui interval } \\
\text { peningkatannya maka dilakukan uji gain score. Adapun }\end{array}$} \\
\hline \multicolumn{5}{|c|}{$\mathrm{g}=\overline{x m a k s-x^{1}}$} \\
\hline \multicolumn{5}{|c|}{$1371-1209$} \\
\hline \multicolumn{5}{|c|}{$g=\frac{1600-1209}{160}$} \\
\hline & & & & \\
\hline
\end{tabular}

\begin{tabular}{lll} 
Aspek & Rata-rata & Kriteria \\
\hline
\end{tabular}


Berdasarkan hasil dari uji gain score maka diperoleh nilai sebesar 0,41 . Mengacu pada tabel tiga nilai tersebut termasuk kategori sedang.

Peningkatan tersebut terjadi dikarenakan pada saat permainan berlangsung setiap peserta didik berkompetisi ingin menjadi pemenang, beberapa peserta didik termotivasi ketika fasilitator atau juri memberikan soal yang jawabannya terdapat pada kartu yang sedang dimiliki setiap peserta, dan ketika ada peserta didik yang mempunyai pemahaman materi yang kurang baik, maka akan menggunakan strategi kartu simbol agar lawannya tidak terus mendapatkan poin, persaingan antar pemain akan menjadi lebih ketat karena diterapkan sistem peringkat berdasarkan perolehan poin.

Peningkatan nilai motivasi belajar tersebut diiringi dengan perubahan perilaku peserta didik pada saat sebelum dan sesudah menggunakan media pembelajaran $U$-Eco. Peserta didik yang awalnya kurang tertarik dengan mata pelajaran ekonomi, lalu setelah diberi perlakuan menjadi lebih tertarik mempelajari pelajaran ekonomi. Peserta didik yang semula sulit memahami materi dengan baik saat menggunakan media papan tulis dan metode ceramah, lalu setelah diberi perlakuan menjadi lebih mudah memahami materi dengan baik. Peserta didik yang awalnya senang mengerjakan tugas secara berkelompok menjadi lebih suka bekerja secara mandiri. Dari uraian tersebut dapat disimpulkan bahwa pemakaian media $U$ Eco dalam pembelajaran cukup meningkatkan motivasi belajar peserta didik.

Hasil penelitian tersebut sesuai dengan pendapat Gage \& Berliner (dalam Slameto, 2010) tentang salah satu cara meningkatkan motivasi belajar peserta didik dengan menggunakan simulasi dan permainan. Motivasi belajar peserta didik meningkat setelah penggunaan media pembelajaran U-Eco. Adapun salah satu teori konstruktivisme yakni teori perilaku BF Skinner yang mendalilkan bahwa teori perilaku adalah fungsi dari konsekuensinya (Kearsley dalam Batson \& Feinberg, 2005). Teori perilaku dalam desain game digunakan untuk mempelajari aturan dasar permainan dan menunjukkan rangsangan terhadap sikap atau perilaku pemain lain. Teori perilaku diterapkan dalam permainan kartu Uno saat permainan berlangung setiap peserta didik saling bersaing ingin menjadi pemenang dalam permainan, setiap pemain memperhatikan juri ketika membacakan soal dengan harapan pemain yang dibacakan soal tersebut tidak mampu menjawabnya agar tidak mendapatkan poin sehingga pemain lain mendapat lemparan soal, peserta didik yang memiliki pemahaman yang kurang baik akan memakai strategi kartu simbol agar pemain lain tidak terus mendapatkan poin. Sehingga, saat setiap pemain menerapkan teori perilaku yang akan membuat permainan menjadi lebih menarik, karena pemenang belum diketahui/sulit diperkirakan (Sadiman et al., 2011).

Kemudian tentang teori relativitas khusus Enstein, yakni teori imersif yang merupakan suatu keadaan pikiran di mana fokus seseorang begitu diarahkan pada suatu topik sehingga segala sesuatu berlalu begitu saja tanpa disadari (Kalmpourtzis, 2019). Teori imersif dialami oleh saat para peserta didik memainkan $U$-Eco, peserta didik mendapat pengalaman imersif, yakni jam pelajaran yang biasanya terasa sangat membosankan dan kurang bergairah seakan waktu berjalan sangat lambat menjadi tidak terasa selambat dan semembosankan seperti biasanya. Dengan kata lain, waktu seakan berjalan lebih cepat daripada biasanya karena mereka benar-benar menikmati permainan. Jadi, saat para peserta didik tenggelam dalam permainan, maka secara tidak sadar mereka telah termotivasi untuk bermain sekaligus belajar.

Hasil penelitian ini diperkuat dengan hasil penelitian Maulana Witantyo dan Diana Rahmawati (2017) yang berjudul "Pengembangan Media Pembelajaran Kartu Uno Akuntansi Untuk Meningkatkan Motivasi Belajar Siswa" yang memiliki hasil penelitian bahwa pengembangan media Kartu Uno dalam pembelajaran Akuntansi mampu meningkatkan motivasi belajar peserta didik sebesar $6,66 \%$ (0,33 setelah melalui uji gain score) dari 79,90\% (sebelum penggunaan media) menjadi $86,56 \%$ (pasca atau sesudah penggunaan media).

Hasil penelitian ini selaras dengan teori yang di paparkan oleh (Sanjaya, 2013) tentang fungsi dan peranan media yakni untuk menambah hasrat dan motivasi belajar peserta didik. Pemakaian media belajar yang baru dan variatif dapat memberi sumbangsih pengalaman baru untuk peserta didik. sehingga, media akan dapat menumbuhkan ketertarikan pada peserta didik. Hal tersebut secara tidak langsung dapat membuat peserta didik lebih semangat. Selaras dengan pendapat yang dijelaskan oleh Arsyad (2016) tentang manfaat praktis penggunaan media pembelajaran pada proses pembelajaran yakni media pembelajaran dapat mengembangkan dan mengarahkan fokus peserta didik sehingga dapat menciptakan motivasi belajar. 


\section{PENUTUP}

\section{Simpulan}

Berdasarkan uraian hasil dan pembahasan, pengembangan media pembelajaran $U$-Eco, dapat disimpulkan bahwa: 1) Pengembangan media pembelajaran $U$-Eco menggunakan model pengembangan 4-D yang terbagi dalam tahap define (pendefinisian), design (tahap perencanaan), delevop (tahap pengembangan), dan tahap disseminate (penyebaran). Namun pada penelitian ini hanya sampai pada tahap pengembangan (develop); 2) Kelayakan media pembelajaran $U$-Eco selaras dengan penilaian para ahli yakni penilaian ahli materi yang memperoleh skor 81 dengan presentase $90 \%$ menunjukkan kategori sangat layak, penilaian ahli media diperoleh skor 107 dengan presentase $93 \%$ menunjukkan kategori sangat layak, penilaian ahli evaluasi menunjukkan butir soal dalam media pembelajaran $U$-Eco telah sesuai dengan indikator pada instrumen penilaian; 3) Peningkatan hasil motivasi belajar peserta didik kelas X-IPS 1 SMA N 4 Bangkalan dapat dilihat berdasarkan perbedaan nilai atau skor motivasi sebelum penggunaan media dan nilai atau skor motivasi sesudah penggunaan media. Hasil penilaian memaparkan terdapat peningkatan motivasi belajar sebesar $10,13 \%$ yakni dari $75,56 \%$ (skor motivasi sebelum penggunaan media) menjadi $85,69 \%$ (skor motivasi sesudah penggunaan media). kedua peneliti memperoleh data interval peningkatan melalui uji gain score dalam penggunaan media pembelajaran U-Eco sebesar 0,41. Peningkatan ini termasuk dalam kriteria sedang sebab nilai gain terdapat pada $0,3 \leqslant X \leqslant 0,7$. Maka dapat disimpulkan bahwa pemakaian media U-Eco mampu meningkatkan motivasi belajar siswa atau peserta didik.

\section{Saran}

Berdasarkan hasil analisis data dan kesimpulan di atas, maka dapat diberikan saran diantaranya: 1) Pengembangan media pembelajaran $U$-Eco hanya melakukan penelitian sampai pada tahap pengembangan (develop). Oleh karena itu, perlu ada penelitian lebih lanjut yang melakukan penelitian hingga tahap penyebaran (disseminate); 2) Sub materi pada media pembelajaran $U$-Eco perlu diperbanyak dalam pengembangan - pengembangan kedepannya untuk mendapat cakupan materi yang lebih banyak dan sesuai dengan materi pembelajaran; 3) Media pembelajaran $U$-Eco dapat menjadi alternatif media yang diterapkan oleh siswa atau peserta didik pada kompetensi atau materi yang lain; 4) Subjek penelitian perlu ditambah agar proses mengukur motivasi belajar pasca pemakaian media tidak cukup satu kelas saja, namun perlu beberapa kelas supaya memperoleh hasil yang lebih baik dan optimal.

\section{DAFTAR PUSTAKA}

Arsyad, A. (2016). Media Pembelajaran (19th ed.). PT RajaGrafindo Persada.

Azizan, M. T., Mellon, N., Ramli, R. M., \& Yusup, S. (2018). Improving teamwork skills and enhancing deep learning via development of board game using cooperative learning method in Reaction Engineering course. Education for Chemical Engineers, 22, 1-13. https://doi.org/10.1016/j.ece.2017.10.002

Baharuddin, \& Wahyuni, E. N. (2015). Teori Belajar dan Pembelajaran (A. Safa (ed.); 1st ed.). Ar-Ruz Media.

Batson, L., \& Feinberg, S. (2005). Game Designs that Enhance Motivation and Learning for Teenagers. Electronic Journal for the Integration of Technology in Education, 5, 34-43.

Hake, R. (1999). Analyzing Change/ Gain Score. Indiana University.

Kalmpourtzis, G. (2019). Educational Game Design Fundamentals. CRC Press.

Lepper, M. R., \& Cordova, D. I. (1992). A Desire to Be Taught: Instructional Consequences of Intrinsic Motivation. Plenum Publishing Corporation, 16(3), 187-208. https://doi.org/10.1007/BF00991651

Nurhasanah, L., Herliawan, \& Pertawati, I. (2013). Efektivitas Teknik Permainan Kartu Uno dalam Pembelajaran Kosakata Bahasa Jerman. Jurnal Pendidikan Bahasa Jerman. http://jerman.upi.edu

Riduwan. (2016). Skala Pengukuran Variabel-Variabel Penelitian (P. D. Iswara (ed.); 3rd ed.). Alfabeta.

Sadiman, A. S., Raharjo, R., Haryono, A., \& Rahardjito. (2011). Media Pendidikan: Pengertian, Pengembangan, dan Pemanfaatannya (S. Natakusumah (ed.); 15 th ed.). Rajawali Pers.

Sanjaya, W. (2013). Strategi Belajar Mengajar Akuntansi. Kencana.

Sari, I. P., Sari, S. A., \& Rahmayani, R. F. I. (2016). PENGEMBANGAN MEDIA KARTU KUARTET PADA MATERI ASAM BASA UNTUK MENINGKATKAN MOTIVASI DAN AKTIVITAS BELAJAR SISWA KELAS VII DI SMP NEGERI 6 BANDA ACEH Abstrak Pendahuluan Metode Penelitian. Jurnal Ilmiah 
Pengembangan Media Pembelajaran U-Eco Untuk Meningkatkan Motivasi Belajar ... Vol.8 No.1 Tahun 2020

Mahasiswa Pendidikan Kimia (JIMPK), 2(1), 1-10.

Slameto. (2010). Belajar dan Faktor-Faktor yang Mempengaruhinya (5th ed.). Rineka Cipta.

Slavin, R. E. (2009). Psikologi Pendidikan: Teori dan Praktik (B. Sarwiji (ed.); 8th ed.). PT Indeks Permata Puri Media.

Sugiyono. (2017). Metode Penelitian: Kuantitatif, Kualitatif, dan $R \& D$ (26th ed.). Alfabeta.

Sung, H. C., \& Ching, G. S. (2012). A case study on the potentials of card game assisted learning. International Journal of Research Studies in Educational Technology, 1(1), 25-31. https://doi.org/10.5861/ijrset.2012.v1i1.64

Supriyono, H., Murtiyasa, B., Rahmadzani, R. F., \& Adhantoro, M. S. (2018). PENERAPAN GAME EDUKATIF UNTUK MENINGKATKAN MOTIVASI. WARTA LPM, 21(1), 30-39.

Trianto. (2007). Model Pembelajaran Terpadu Dalam Teori dan Praktek (J. Wolor (ed.); 1st ed.). Prestasi Pustaka.

Turkay, S., Adinolf, S., \& Tirthali, D. (2012). Collectible card games as learning tools. Procedia - Social and Behavioral Sciences, 46, 3701-3705. https://doi.org/10.1016/j.sbspro.2012.06.130

Winkel, W. S. (2004). Psikologi Pendidikan dan Evaluasi Belajar. PT Gramedia Pustaka Utama.

Wityanto, M., \& Rahmawati, D. (2017). PENGEMBANGAN MEDIA PEMBELAJARAN KARTU UNO. Kajian Pendidikan Akuntansi Indonesia, 4, 1-17. 